\title{
ADJUVANT TREATMENTS IN MELANOMA
}

\author{
LUKA SIMETIĆ, KREŠIMIR BLAŽIČEVIĆ and DAVORIN HERCEG
}

Medical Oncology Department, University Hospital Center Zagreb, Zagreb, Croatia

\section{Summary}

For decades, interferon-alpha (IFN- $\alpha$ ) has been the only option in the adjuvant treatment of high-risk melanoma. Despite numerous clinical trials and meta-analyzes, IFN- $\alpha$ is not yet a gold standard. It indeed showed benefit in progressionfree survival (PFS) and to a lesser extent in overall survival (OS) but at the cost of high toxicity.

The emergence of new, revolutionary therapies in the treatment of metastatic melanoma, like immunotherapy (checkpoint inhibitors - CTLA4 and PD1 inhibitors) and targeted therapies (BRAF and MEK inhibitors), led to considering their potential effect in adjuvant/preventive use.

A number of phase II and phase III trials analyzed the adjuvant application of targeted therapies and immunotherapies in completely resected stage III melanoma (IIIA, IIIB, IIIC) and stage IV melanoma (PD1 inhibitor nivolumab). They showed a clear benefit in relapse-free survival (RFS) and overall survival (OS). This led to a change in guidelines for adjuvant treatment of melanoma and approval of immunotherapy and targeted therapy by the FDA (Food and Drug Administration) and EMA (European medicines agency) in the indications mentioned above.

Further trials are underway in other high-risk stages (like IIC) and in neoadjuvant treatment of stage III melanoma.

Keywords: melanoma, adjuvant therapies, BRAF and MEK, immunotherapy

\section{INTRODUCTION}

Melanomas are one of the most aggressive types of malignant tumors in humans. Historically, metastatic disease ended fatally in most of the patients within one year of diagnosis. As the only systemic therapy option (with eventual surgery), Dacarbazine-based chemotherapy had a modest effect on survival. Stage III melanoma (involvement of regional lymph nodes) also meant a poor prognosis. This stage represents a heterogeneous group, meaning that $88 \%$ of patients with stage IIIA are alive after ten years while only $24 \%$ of patients are alive with stage $\operatorname{IIID}(1)$ (according to the latest 8th AJCC classification -American Joint Committee on Cancer, 8th edition). These data have encouraged the idea of preventive/adjuvant

Correspondence author: Luka Simetić, Medical Oncology Department, University Hospital Center Zagreb, Kišpatićeva 12, 10000 Zagreb, Croatia.e-mail: lsimetic@kbc-zagreb.hr therapy after surgical treatment of stage III disease. Historically, IFN- $\alpha$ has been the only option in adjuvant melanoma therapy for decades, despite the only modest effect on disease outcomes (PFS and OS) and relatively poor tolerability(2). With the emergence of modern, effective therapies in metastatic disease (targeted therapies and immune checkpoint inhibitors), trials in the adjuvant setting have begun. The purpose of this article is to present current states of adjuvant therapy in stage III melanoma and to provide some future perspectives in the treatment of locally advanced melanoma.

\section{METHODS AND MATERIALS}

We searched the PubMed ${ }^{\circledR}$ medical bibliographic database by terms: adjuvant therapy in stage III and IV melanoma, targeted therapy, and 
immunotherapy with a focus on phase II-III studies, meta-analyses, and systematic reviews.

\section{RESULTS AND DISCUSSION}

The first positive phase III adjuvant study that demonstrated the benefit of ipilimumab (Cytotoxic T-Lymphocyte Associated Protein 4, CTLA-4 inhibitor) in progression-free survival (PFS) and later overall survival (OS) was EORTC 18071(3). Ipilimumab was tested in completely resected stage III melanoma (IIIA, IIIB, IIIC) at a dose of $10 \mathrm{mg} / \mathrm{kg}$ i.v. every 3 weeks to a total of 4 doses then $10 \mathrm{mg} / \mathrm{kg}$ i.v. every 12 weeks for a total of 3 years versus the placebo-receiving cohort. The study included a total of 951 patients with completely resected stage III cutaneous melanoma. After a median follow-up of 6.9 years, the benefit was shown in all subgroups in PFS with a hazard ratio (HR) 0.75, as well as in distant metastasisfree survival (DMFS) with HR of 0.76 and overall survival with an HR of 0.73 . Treatment toxicity was extremely high $(10 \mathrm{mg} / \mathrm{kg}$ was three times higher than the standard dose for metastatic melanoma), especially in the spectrum of autoimmune side effects. Five deaths due to autoimmune side effects have been reported! Subsequent positive adjuvant studies with anti PD-1 inhibitors led to the abandonment of ipilimumab as a standard of care in the adjuvant setting because the toxic profile of anti-PD1 inhibitors was significantly more favorable. It is worth noting that ipilimumab also showed benefit in another phase III trial, E1609, compared to the previous standard of care - highdose IFN- $\alpha 2 b$, which was used as a control group active comparator(4).

Nivolumab, PD-1 inhibitor (Programmed cell death protein 1), was tested in phase III adjuvant trial CheckMate 238(5). The trial included 906 patients with completely resected stage III (IIIB, IIIC) and completely resected stage IV. The purpose was to determine whether nivolumab is better than ipilimumab in the prevention of recurrences in melanoma. The first cohort of patients received nivolumab at a dose of $3 \mathrm{mg} / \mathrm{kg}$ i.v. every 2 weeks for a year, and the second cohort received ipilimumab at a dose of $10 \mathrm{mg} / \mathrm{kg}$ i.v. for a year. After 18 months of follow-up, $63 \%$ of patients receiving nivolumab had no relapse compared with $53 \%$ of patients receiving ipilimumab. Nivolumab showed benefit in all subgroups of patients in relapse-free survival (RFS), distant metastases-free survival (DMFS), and overall survival (OS) compared to ipilimumab with a significantly lower frequency of autoimmune side effects(6).

Pembrolizumab, another PD-1 inhibitor, also showed benefit in all subgroups of patients in RFS, DMFS, and OS relative to the second cohort receiving matched placebo in phase III trial Keynote-054(7). A total of 1019 patients were randomized in two cohorts. Patients in the pembrolizumab cohort received a dose of $200 \mathrm{mg}$ i.v. fixed every 3 weeks for a year. After 18 months of follow-up, $71.4 \%$ of patients in the pembrolizumab cohort had no signs of disease recurrence compared with $53.2 \%$ in the placebo cohort (HR 0.57).

The Immuned trial tested adjuvant immunotherapy with nivolumab plus ipilimumab or nivolumab plus ipilimumab placebo versus double placebo control as a post-surgical/post-radiation treatment for stage IV melanoma with no evidence of disease (NED). This was a phase 2 trial that included a total of 167 patients(8). Patients were randomized in three arms. In the experimental arm (ipi-nivo) they received a combination of nivolumab with ipilimumab (4 applications of nivolumab $1 \mathrm{mg} / \mathrm{kg}$ with ipilimumab $3 \mathrm{mg} / \mathrm{kg}$ followed by nivolumab $3 \mathrm{mg} / \mathrm{kg}$ ), in the active comparator arm a combination of nivolumab $(2 \mathrm{mg} / \mathrm{kg})$ with matched placebo and in the placebo comparator arm a combination of double placebo (control). Patients with uveal and mucosal melanomas were excluded. After 28.4 months of follow-up, the median disease recurrence time in the ipi-nivo arm was still not reached, while in the nivolumab arm, it was 12.4 months, and in the placebo arm, 6.4 months. HR for ipi-nivo arm was $0.23(97.5 \%$ CI $0.12-0.45 ; \mathrm{p}<0.0001)$, and for mono nivolumab arm $0.56(0.33-0.94 ; \mathrm{p}=0.011)$. In the ipi-nivo arm after 2 years, $70 \%(55.1-81.0)$ of patients had no signs of disease recurrence, while in the nivolumab group, $42 \%(28.6-54.5)$ of patients were disease-free, and in the placebo group, only $14 \%$ (5.9-25.7). The cost of excellent results in the ipi-nivo group was compromised by treatment-related adverse events (autoimmune side-effects), with $71 \%$ of patients experiencing grade 3-4 events, while this percentage was $27 \%$ (16-40) in the nivolumab group. As many as $62 \%$ of patients in combination ipi-nivo arm discontinued treatment due to treatment-related adverse events of any grade. 
Besides immunotherapy, targeted therapy with BRAF and MEK inhibitors has yielded positive results in the adjuvant treatment of stage III melanoma. A prerequisite for the aforementioned targeted therapy was the existence of B-RAF mutation!

In phase III trial COMBI-AD, a total of 870 patients with completely resected stage III melanoma (IIIA - lymph node metastasis greater than 1 $\mathrm{mm}$, IIIB and IIIC) were randomized into two cohorts(9). The first cohort received a combination of BRAF inhibitor dabrafenib (2x150mg p.o. daily) and MEK inhibitor trametinib (2mg p.o. daily). The second cohort received two matched placebo tablets for a total of 12 months.

The primary endpoint was relapse-free survival (RFS), and secondary endpoints were overall survival (OS), distant metastases-free survival (DMFS), freedom from relapse (FFR), and safety.

After 4 years of follow-up, $54 \%$ of patients in the combination group had no signs of relapse (RFS), while in the placebo group, only $38 \%$ of patients had no recurrence, with HR 0.49. Regarding overall survival, $86 \%$ of patients in the combination group were alive after 3 years, while $77 \%$ of patients in the placebo group were alive, with HR 0.57 . The side effect profile was identical to those seen in metastatic trials of targeted therapy, with no therapy-related deaths noted.

Kirkwood et al.(10) used additional statistical tools (Restricted mean survival time - RMST; a method that takes into account the average duration of response within a population by taking into account the area under the survival curve to a defined point in time) and calculated that the patients treated with adjuvant dabrafenib and trametinib received an additional 12.8 months without disease relapse compared to the placebo group over the 60-month follow-up period.

An additional statistical tool showing the benefits of adjuvant BRAF and MEK therapy is the Cure-rate model. This model uses time until the manifestation of the event and allows the assessment of the ratio of patients from both cohorts who will never experience the expected event (disease relapse). The difference between the two cohorts was $16 \%$ in favor of the group of patients taking dabrafenib and trametinib, which represents an additional protective effect of the therapy.

Further trials of immunotherapy and targeted therapy (BRAF and MEK inhibitors) in the neo- adjuvant setting are ongoing. A phase II trial OpACIN-neo (11) examined neoadjuvant use of combination immunotherapy (anti-CTLA-4 plus anti-PD-1) in patients with stage III melanoma. It showed a high degree of complete pathological responses (which proved to be a surrogate marker for prolonged PFS and OS)(11). The PRADO trial(12) was an extension cohort of the aforementioned OpACIN-neo trial. It showed that patients who have achieved a complete pathological response on neoadjuvant immunotherapy could potentially be spared of surgery, representing one of the precedents in oncology. Similar trials are ongoing with targeted therapy (NeoCombi phase II trial)(13) which showed a high percentage of complete pathological responses to neoadjuvant administration of dabrafenib and trametinib in BRAF mutated stage IIIB-IIIC melanoma.

Nowadays, additional emphasis is on testing new therapeutic strategies in high-risk stage II melanoma, such as stage IIC, which in terms of overall survival has worse outcomes than stage IIIA.

\section{CONCLUSION}

Adjuvant therapy with BRAF and MEK inhibitors and immunotherapy (PD-1 inhibitors) in completely resected stage III and stage IV (nivolumab only) have become the gold standard of care(14). After a long time, these therapies have led to improved outcomes in stage III melanoma (relapse-free survival, overall survival). However, despite the protective effect of the therapies mentioned above, many questions remain open: can we expect better outcomes if we extend the duration of adjuvant treatment? Which option to choose as adjuvant treatment for BRAF mutated melanoma? How to assess potential side effects in relation to the benefit?

On the other hand, the problem is also financial, looking at the cost of a one-year treatment. Furthermore, neoadjuvant trials are underway in stage III. Finally, the question remains could we potentially avoid surgery in some stage III patients or, perhaps, define adjuvant treatment based on a neoadjuvant approach and pathological response and thus improve outcomes.

\section{Acknowledgments:}

Pharmaceutical companies or work institutions did not fund this article. It is copyright work. 


\section{REFERENCES}

1. Keung EZ, Gershenwald JE. The eighth edition American Joint Committee on Cancer (AJCC) melanoma staging system: implications for melanoma treatment and care. Expert Rev Anticancer Ther. 2018;18(8):775784. doi:10.1080/14737140.2018.1489246

2. Mocellin S, Pasquali S, Rossi CR, Nitti D. Interferon alpha adjuvant therapy in patients with high-risk melanoma: a systematic review and meta-analysis. J Natl Cancer Inst. 2010 Apr 7;102(7):493-501. doi: 10.1093/ jnci/djq009.

3. Eggermont AMM, Chiarion-Sileni V, Grob JJ. Adjuvant ipilimumab versus placebo after complete resection of stage III melanoma: long-term follow-up results of the European Organisation for Research and Treatment of Cancer 18071 double-blind phase 3 randomised trial. Eur J Cancer. 2019 Sep;119:1-10. doi: 10.1016/j.ejca.2019.07.001.

4. Tarhini AA, Lee SJ, Hodi FS, Rao UNM, Cohen GI, Hamid O, et al. Phase III Study of Adjuvant Ipilimumab (3 or $10 \mathrm{mg} / \mathrm{kg}$ ) Versus High-Dose Interferon Alfa-2b for Resected High-Risk Melanoma: North American Intergroup E1609. J Clin Oncol. 2020 Feb 20;38(6):567575. doi: 10.1200/JCO.19.01381.

5. Weber J, Mandala M, Del Vecchio M, Gogas HJ, Arance AM, Cowey CL, et al. Adjuvant Nivolumab versus Ipilimumab in Resected Stage III or IV Melanoma. N Engl J Med. 2017 Nov 9;377(19):1824-1835. doi: 10.1056/NEJMoa1709030.

6. Ascierto PA, Del Vecchio M, Mandalá M, Gogas $H$, Arance AM, Dalle S, et al. Adjuvant nivolumab versus ipilimumab in resected stage IIIB-C and stage IV melanoma (CheckMate 238): 4-year results from a multicentre, double-blind, randomised, controlled, phase 3 trial. Lancet Oncol. 2020 Nov;21(11):1465-1477. doi: 10.1016/S1470-2045(20)30494-0.

7. Eggermont AMM, Blank CU, Mandala M, Long GV, Atkinson V, Dalle S, et al. Pembrolizumab versus Placebo in Resected Stage III Melanoma. N Engl J Med. 2018 May 10;378(19):1789-1801. doi: 10.1056/NEJMoa1802357.

8. Zimmer L, Livingstone E, Hassel JC, Fluck M, Eigentler T, Loquai C, et al., Dermatologic Cooperative Oncology Group. Adjuvant nivolumab plus ipilim- umab or nivolumab monotherapy versus placebo in patients with resected stage IV melanoma with no evidence of disease (IMMUNED): a randomised, doubleblind, placebo-controlled, phase 2 trial. Lancet. 2020 May 16;395(10236):1558-1568. doi: 10.1016/S0140-6736 (20)30417-7.

9. Long GV, Hauschild A, Santinami M, Atkinson V, Mandalà M, Chiarion-Sileni V, et al. Adjuvant Dabrafenib plus Trametinib in Stage III BRAF-Mutated Melanoma. N Engl J Med. 2017 Nov 9;377(19):18131823. doi: 10.1056/NEJMoa1708539.

10. Kirkwood M.J, Dummer R., Hauschild A. et al. Restricted mean survival time (RMST) and cure-rate modeling in estimating survival benefit with adjuvant dabrafenib (D) plus trametinib (T) treatment in melanoma. Ann Oncol 2020; doi: https://doi.org/10.1016/j. annonc.2020.08.1223

11. Rozeman EA, Menzies AM, van Akkoi. Identification of the optimal combination dosing schedule of neoadjuvant ipilimumab plus nivolumab in macroscopic stage III melanoma (OpACIN-neo): a multicentre, phase 2, randomised, controlled trial. Lancet Oncol. 2019 Jul;20(7):948-960. doi: 10.1016/S1470-2045(19) 30151-2.

12. Reijers I, Rozeman EA, Menzies MA, Van De Wiel BA. First safety and efficacy results of PRADO: A phase II study of personalized response-driven surgery and adjuvant therapy after neoadjuvant ipilimumab (IPI) and nivolumab (NIVO) in resectable stage III melanoma. Journal of Clinical Oncology 38, no. 15_suppl (May 20, 2020) 10002-10002 DOI: 10.1200/JCO.2020. 38.15_suppl.10002

13. Long GV, Saw RPM, Lo S, Nieweg OE, Shannon KF, Gonzalez M, et al. Neoadjuvant dabrafenib combined with trametinib for resectable, stage IIIB-C, BRAFV600 mutation-positive melanoma (NeoCombi): a singlearm, open-label, single-centre, phase 2 trial. Lancet Oncol. 2019 Jul;20(7):961-971. doi: 10.1016/S1470-2045 (19)30331-6..

14. Longo C, Pampena R, Lallas A, Kyrgidis A, Stratigos A, Peris K, et al. Adjuvant therapy for cutaneous melanoma: a systematic review and network meta-analysis of new therapies. J Eur Acad Dermatol Venereol. 2020 May;34(5):956-966. doi: 10.1111/jdv.16074. 


\section{Sažetak}

\section{ADJUVATNO LIJEČENJE MELANOMA}

\section{Simetić, K. Blažičević, D. Herceg}

Desetljećima je interferon alfa bio jedina opcija u adjuvatnoj terapiji visokorizičnog melanoma. Unatoč brojnim studijama i meta analizama, interferon nije zaživio kao zlatni standard liječenja visokorizičnog melanoma. Pokazao je svakako benefit u vremenu do progresije bolesti (PFS, progression free survival) te u manjem dijelu u ukupnom preživljenju (OS, overall survival) pod cijenu visoke toksičnosti.

Pojavom revolucionarnih terapija u liječenju metastatskog melanoma; imunoterapije, anti CTLA-4 (cytotoxic T-lymphocyte-associated protein 4) i anti PD-1 inhibitora (programmed cell death protein 1) te ciljane terapije (BRAF i MEK inhibitori) razmišljalo se o njihovom potencijalnom učinku u adjuvatnom/preventivnom smislu.

Brojne studije faze II i III ispitivale su adjuvantnu primjenu ciljane terapije i imunoterapije u kompletno reseciranom stadiju III (IIIA, IIIB, IIIC) i stadiju IV (anti PD-1 inhibitor nivolumab). Pokazale su jasan benefit u vremenu do povratka bolesti (PFS) i ukupnom preživljenju (OS). Navedeni rezultati su promijenili smjernice za adjuvantnu terapiju kod melanoma u vidu registracije imunoterapije te ciljane terapije od strane FDA (Food and drug administration) i EMA (European medicines agency) za adjuvantnu primjenu. U tijeku su daljnja ispitivanja i u drugim visokorizičnim stadijima (npr. IIC) te neoadjuvantno liječenje stadija III.

KLJUČNE RIJEČI: melanom, adjuvantna terapija, BRAF i MEK, imunoterapija 